\title{
素足での床のすべりの評価方法に関する研究 \\ STUDY ON THE EVALUATION METHOD OF SLIPPERINESS \\ OF FLOORS WITH BARE FEET
}

\author{
小野英哲*, 落合 昇** \\ Hidenori ONO and Noboru OCHIAI
}

This paper presents the evaluation method of floors with bare feet.

The first, in order to obtain slip resistance of floors with bare feet, the new slider of O-Y·PSM (Slip tester developed by author in former research)was developed by author, and the physical value C.S.R $\cdot B F$ (Coefficient of Slip Resistance with Bare Feet) was established.

The second, sensory test was carried out to make the evaluation scales of slipperiness of floors using with bare feet.

Finally, it was showed that C.S.R $\cdot B F$ corresponded to the evaluation scales, and the evaluation method of slipperiness of floors with bare feet was presented by means of correspondence.

Keywords : Slipperiness of floors, Slip resistance, Bare feet, New slider, Evaluation method 床のすべり，すべり抵抗，素足，新たなすべり片，評価方法

\section{1. 序}

小野らはこれまで，人間が履物を装着した場合の床，路面，斜路， 階段，スポーツサーフェイス（以降，一括して床と呼ぶ）のすべり の評価方法を提示している1) 12)。

一方，素足での床のすべり（以降，単にすべりまたは素足でのす べりと呼ぶ）に関しては，国内外において小野らによる限定された 条件下での評価方法が提示されているのみである13).14)。

このような状況のなかで，素足での使用に供する住居床などでの 転倒事故例, 武道場床でのすべりの不適切さの指摘や障害発生事例, などがいまだに多い。表 1 は，素足で競技する武道競技者に対して 1999 年に行ったすべりに関するアンケート調查結果の一部である。 表から多くの競技者がすべりを気にしているのが明確で，よりよい すべりをもつ床が望まれている背景を示す例とみることができる。

\section{表 1 床のすべりに関するアンケート調査結果}

\begin{tabular}{|c|c|c|c|c|}
\hline 競技種目 & 調查人数 $\mathrm{A}$ (人) & 競技歷 (年) & \begin{tabular}{|l} 
すべりが気に \\
なると回答し \\
た人数 $\mathrm{B}(\Lambda)$
\end{tabular} & B/A (\%) \\
\hline 剣道 & 26(男26,女0) & $10 \sim 45$ & 21 & 80 \\
\hline 空手 & 22(男 20, 女 2) & $2 \sim 20$ & 17 & 77 \\
\hline 少林寺拳法 & 89 (男 86 ，女 3 ) & $2 \sim 32$ & 46 & 51 \\
\hline 総計 & & & 84 & 61 \\
\hline
\end{tabular}

本論文は，以上の背㔀から，素足での使用に供する床の開発，設 計，選択，維持管理などの場面で必要不可欠な検討事項となるすべ りを測定，評価できる方法を考究した経過および結果を述べるもの である。

\section{2.目的と管围}

本研究の目的は素足でのすべりの評価方法を提示することにある。 ここで，対象とする床は素足での使用に供する水平な床とし，昇 る, 降りるなどの動作が主となる階段, 段差, さらには, すでに成 果を公表しているきわめてすべりやすい液状の物質が常時表面に介 在する浴槽底，浴室床など ${ }^{3}$ ），14， は範囲外と寸る。具体的には, 激しい動作に供する武道場床と, 日常生活における一般的な動作に 供する居問，廊下：ホールなどの床，を対象とする。

また，対象とする使用者の層は健常な成人とし，高畧者等に関し ては今後の課題とする。

なお, 様々な床のすべりの評価, 最適なすべりをもつ床の仕様の 提示，などは籍囲外とする。

\section{3. 既往の研究}

履物を装着した場合のすべりに関する研究成果は国内外において
* 東京工業大学 教授・工博

** 大成建設俳 修士 (工学) (当時果京工業大学 大学院生)
Prof., Tokyo Institute of Technology, Dr. Eng.

Taisei Corporation, M. Eng. 
数多いが，これら既往のおもな研究に関する検討は小野らによる論 文1)〜4)に詳述しているので本論文での紹介は割愛する。

一方, これらの研究のなかで，床の用途さらには履物や動作の種 類を要因として取り込んだ上で，安全性や快適性の観点からの評価 指標を含めた評価方法を提示しているのは小野らによる成果だけと いえる1) 12)。

この研究では，まず人間が感じるすべりと相関の高いすべり抵抗 を測定できる図 1 に示すすべり試験機 (以降, O-Y・P S M と呼ぶ) を開発している。O-Y·P S Mは，すべり片台座に実際に使用する 履物の底を取り付け，重鍾によりすべり片に $80 \mathrm{kgf}$ の鉛直荷重を載 荷しながら，所定の前置き時間 (0 秒)，荷重速度 $(80 \mathrm{kgf} / \mathrm{sec})$ で 引張った時に得られる図 2 に例示寸る引張荷重・時間曲線から最大 荷重 (Pmax) を求めるものである。すべり抵抗 (C. S . R) は [Pmax (kgf) /80 (kgf)] として求め, 図 3 に例示するすべりの評価指標を 用いて，当該床のすべりを評価するもので，このうち，すべり抵抗 の測定方法はJISにも規定されている15)。

一方，小野らは，浴槽底およびセラミックタイル仕上げを主とす る浴室床を対象に，素足でのすべりの評価を可能としている13）.14）。

すなわち，すべり試験機としては，図 1 に示すO-Y·P SMを用 い，すべり片を図 4 に示すものとして，上述と同じ条件で引張った 時に得られる図 2 に例示寸る引張荷重・時間曲線から, 最大荷重 (Pmax) と最初の凹部の荷重（Pmin）を求めてすべり抵抗（C.S. $\mathrm{R} \cdot \mathrm{B})[\mathrm{Pmax}(\mathrm{kgf}) / 80(\mathrm{kgf})+\mathrm{Pmin}(\mathrm{kgf}) / 80(\mathrm{kgf})]$ を算出
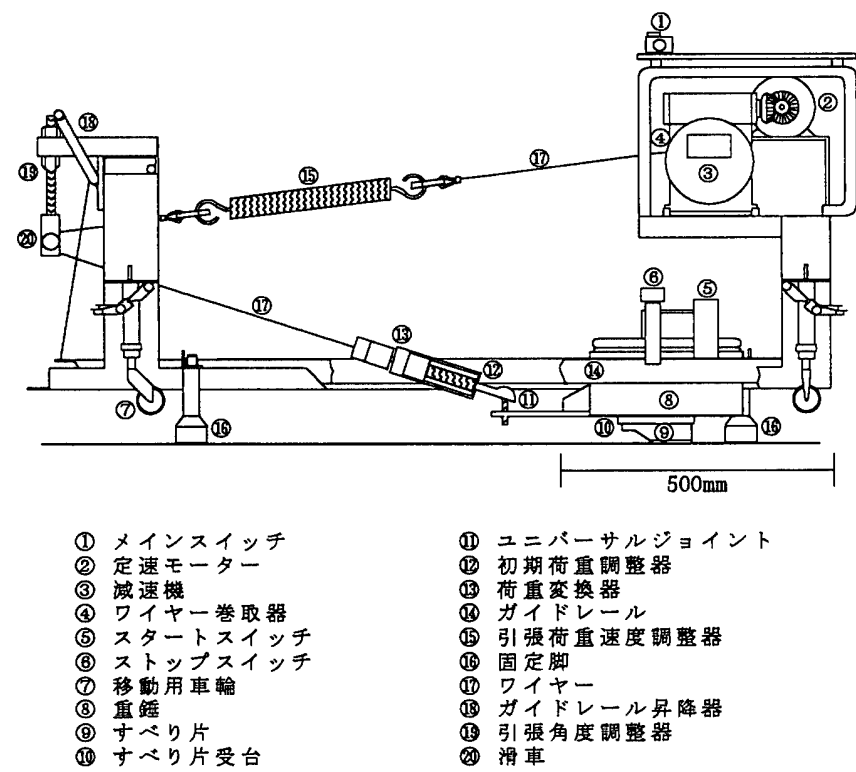

図 1 すべり試釱機 $(\mathrm{O}-\mathrm{Y} \cdot \mathrm{P}$ S M ) の概要

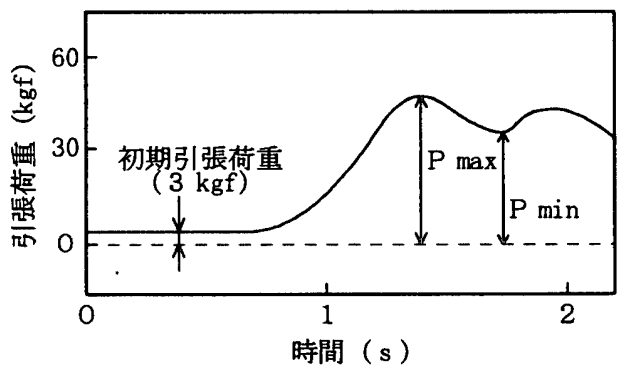

図 2 引張荷重・時間曲線の例
し，図 5 に例示する評価指標を用いて当該床のすべりを評価する方 法である。この研究では, 当初あらゆる場合の素足でのすべりを評 価できる方法を提示することを目標としたが，妥当なすべり片を開 発することが出来ず，限定された条件下における評価方法の提示に とどまっている。

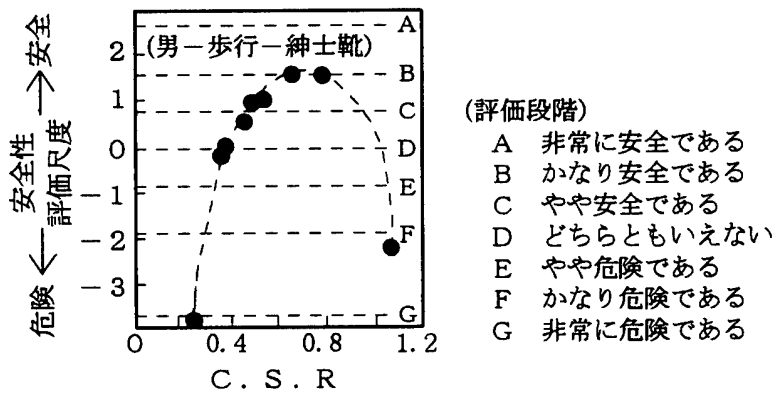

図 3 旅履きでのすべりの評価指標（事務所床等）の例



図 4 すぺり片（浴槽床, 浴室床素足用）の詳細

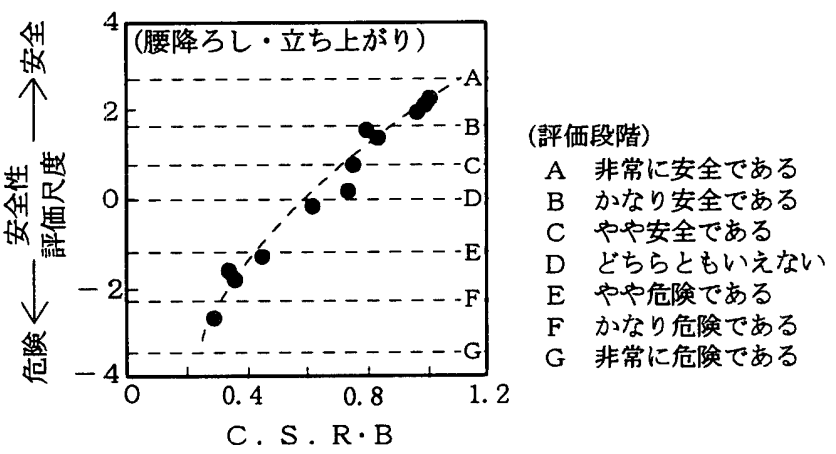

図 5 素足でのすべり（浴槽底，浴室床）の評価指標の例

\section{4. 研究方法}

本研究におけるすべり抵抗の測定には，すべり片を新たに開発す ることを前提として図 1 に示すO-Y·P SMを使用すること, 対象 とする床の表面状態は清掃状態の他, 水, ほこりなどの表面介在物 の介在も想定した状態とすること, を条件として以下の方法で研究 を進めることとした。

（1）様々なすべりをもつ試料床で, 素足で所定の動作を行った場 合に感じる試料休のすべりの大小を官能検查手法を用いて,すべり 感覚尺度として尺度化する。

（2）すべり感覚尺度を表示するすべり抵抗が得られるように○Y・P SMのすべり片を開発する。 
（3）様々なすべりをもつ試料床で, 素足で所定の動作を行った場 合に感じるすべりの良否を官能検査手法を用いて，すべり評価尺度 として尺度化する。

(4)すべり評価尺度とすべり抵抗の対応を素足でのすべりの評価 指標として設定する。

（5）（1）〜（4）から素足でのすべりを評価する方法を提示す る。

なお，すべりを心理学的尺度として把握する理由および妥当性に 関しては既往の研究1) 穴で論究，実証しているので割愛する。

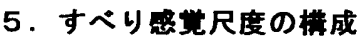

5. 1. すべり感覚尺度構成のための官能検査の概要

5. 1 . 1 検査手法の選定

検査手法は、標準試料との比較により表

2 に示す判断範ちゅうを用いて試料のすべ りの大小の比較判断を求める系列範ちゅう 法とした。

5. 1.2 検查試料の設定

表 2 判断範ちゅう

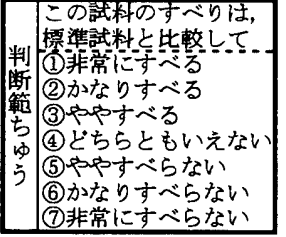

検査試料の設定に当たっては，すべりの範囲を大きくすることを 主眼とし，その他，できるだけ多様な材料を含むこと，不都合な痛 さを感じないこと，表面介在物の影響も考慮すること，などを条件 とし，表 3 に示す１9の試料（№. 12 は標準試料）を設定した。また， 表面介在物に関しては既往の研究成果 ${ }^{8)}$ を参考に, パウダーはほこ り, 水ダストは水や水とほこりの混合物, 泡状石けん水は非常にす ベりやすい物質，にそれぞれ近似する表面介在物として設定した。

なお，試料の大きさは 各々本研究の目的を達成 する上で十分な大きさで ある $180 \mathrm{~cm} \times 90 \mathrm{~cm}$ とした。 試料は図 6 に示すよう に, 標準試料を固定し,他 の試料は検査の都度所定

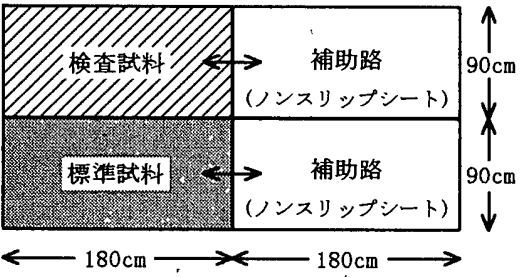

図 6 試料の設置状況の概要
の位置に設置することとした。

\section{1.3 検查員および動作の選定}

検査員，動作および動作と試料の組合せは表 3 に示したとおりで ある。ここで，標準試料と比較する試料のすべりの大小の判断に， 性, 年齢などによる大きな差異はないと想定されたことから, 検査 員は成人男女の混成とした。

また, 動作としては, 本研究で対象とする床における代表的な動 作として, 步行, 駆け出し, 急停止の他, 方向転換などをも含む自 由動作，を選定した。

なお，代表的な動作の検查においては感覚尺度の構成の可能性を 探ることを主目的とすることから，検査の効率を計るため, 自由動 作の場合と比較し各々少ない検查員, 試料数とした。

5. 1.4 検查室および素足の管理

素足での検查においては，検查室および素足表面の状況をできる だけ一定にする必要があるため, 検査室は温度 $20 \sim 23^{\circ} \mathrm{C}$, 湿度 29 〜 33\%RH, とし, 検査員は検查 10 分前に検查室 $(7 \mathrm{~m} \times 4 \mathrm{~m}$, 高さ 2.9m）に入室して検查室の環境に順応した上で, 各試料の判断ごと に清浄な布で足裹を拭くこととした。

\section{2. オべり感覚尺度の構成および考察}

5.1.に述べた条件で官能検查を実施した。

官能検查の分散分析結果を表 3 に示す。

いずれの検查においても主効果が高度に有意でかつ寄与率も大き いことから, 検查は有効であり, 検查員はすべりの大小に関し共通 の判断基準を有しているといえる。なお，個人差が有意な場合もあ るが，寄与率が主効果と比較してきわめて小さいことから，すべり の大小の判断に多少の個人差があることを前提とすれば大きな問題 ではなく，構成される感覚尺度は十分有効と言える。

以上から, 尺度構成理論 ${ }^{16)}$ ) 基づきすべり感覚尺度を構成した。 図 7 に 4 つの動作の検査に共通する試料の感賞尺度の関係を示す。 図から，4つの感覚尺度の相関は非常に高く, 動作にかかわらず, 試 料のすべりの大小の判断の序列は変わらないといえる。つまり，ひ

表 3 検查試料, 検查項目, 動作, 検查員, および分散分析結果

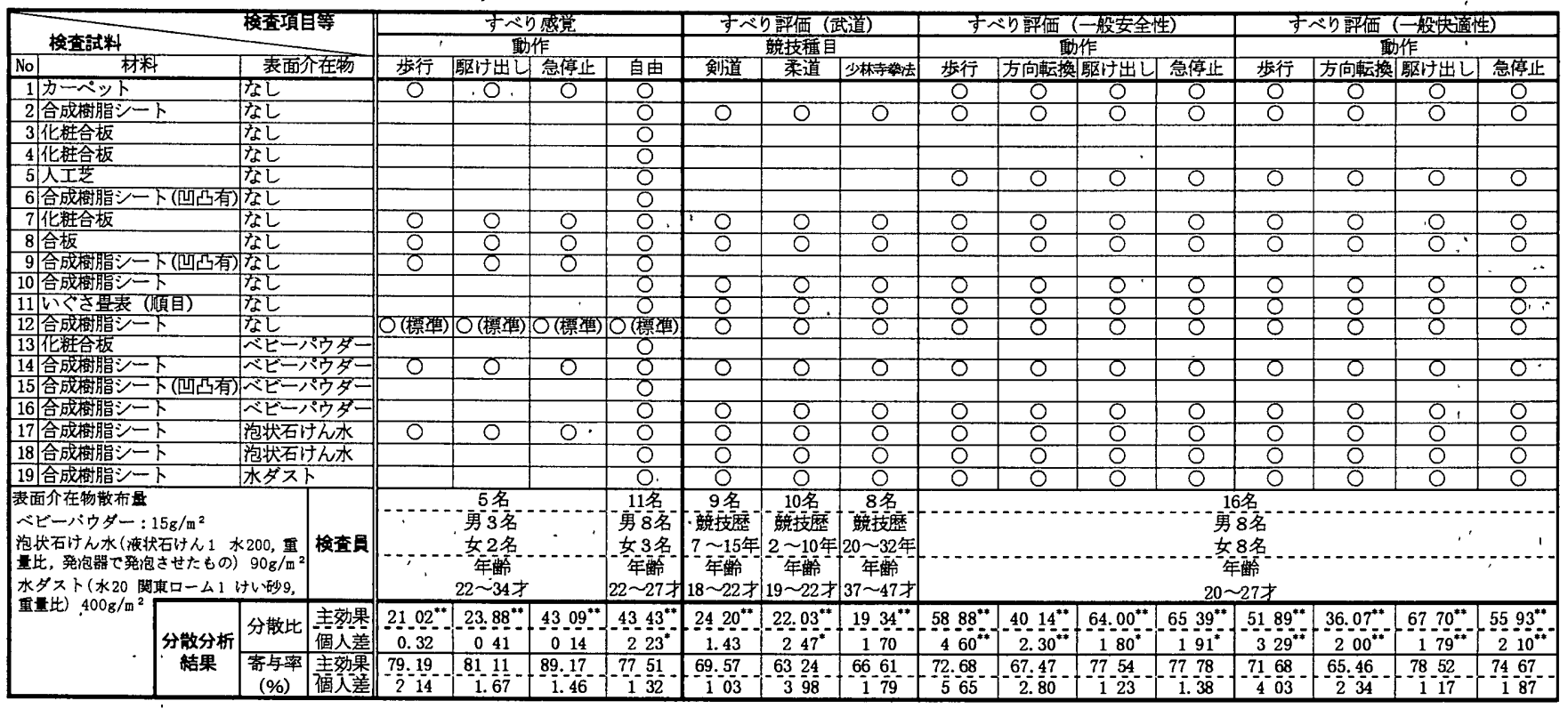

\#:危険率 $1 \%$ で有意, ${ }^{*}$ : 危険率 $5 \%$ で有意 
とつの妥当な測定方法によるすべり抵抗であらゆる動作の場合のす ベりの大小を表示できるといえる。

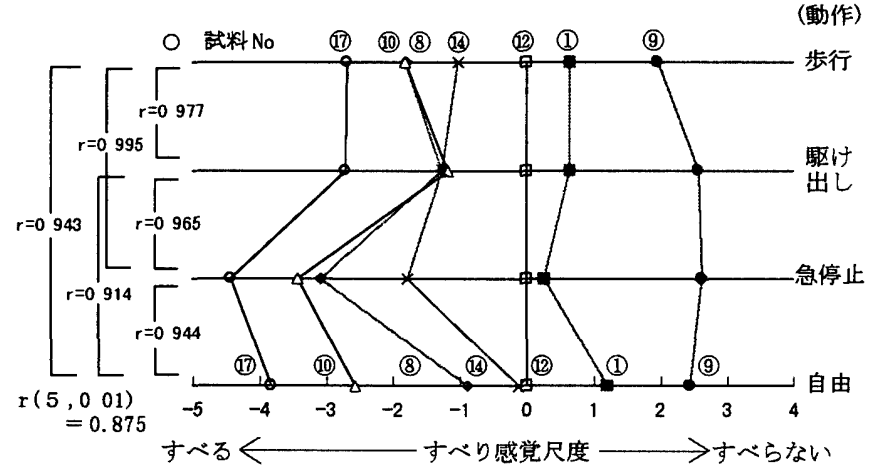

図 7 すべり感営尺度の相関

\section{6.すベり感兗尺度を表示するすへり抵抗の設定}

5.で構成したすべり感覚尺度となめらかに対応するすべり抵抗 を以下の方法で設定することとした。

まず，O-Y·P S Mの，すべり片を，すべり感覚尺度となめらか に対応するすべり抵抗（以降，C．S.R・BFと呼ぶ）が得られる よう試行錯誤的に開発することとした。

幾多の試行を重ね結果として図 8 に示すすべり片を開発した。 図 9 にすべり感覚尺度とC. S.R・B F の対応を示す。なお，C
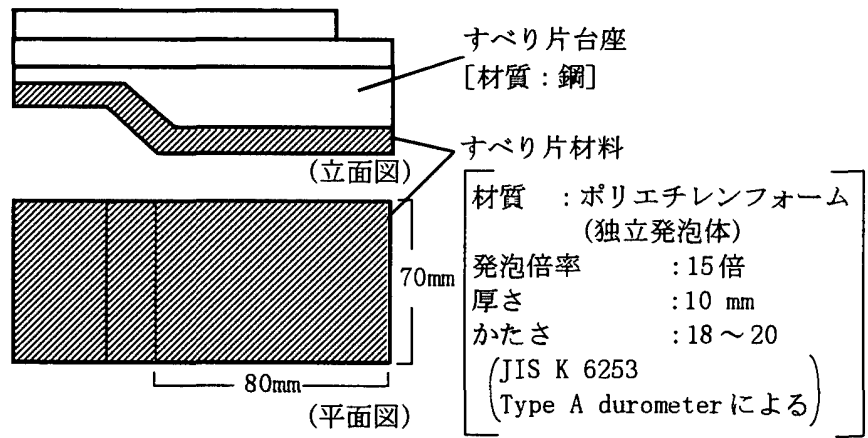

図 8 ナべり片の詳細

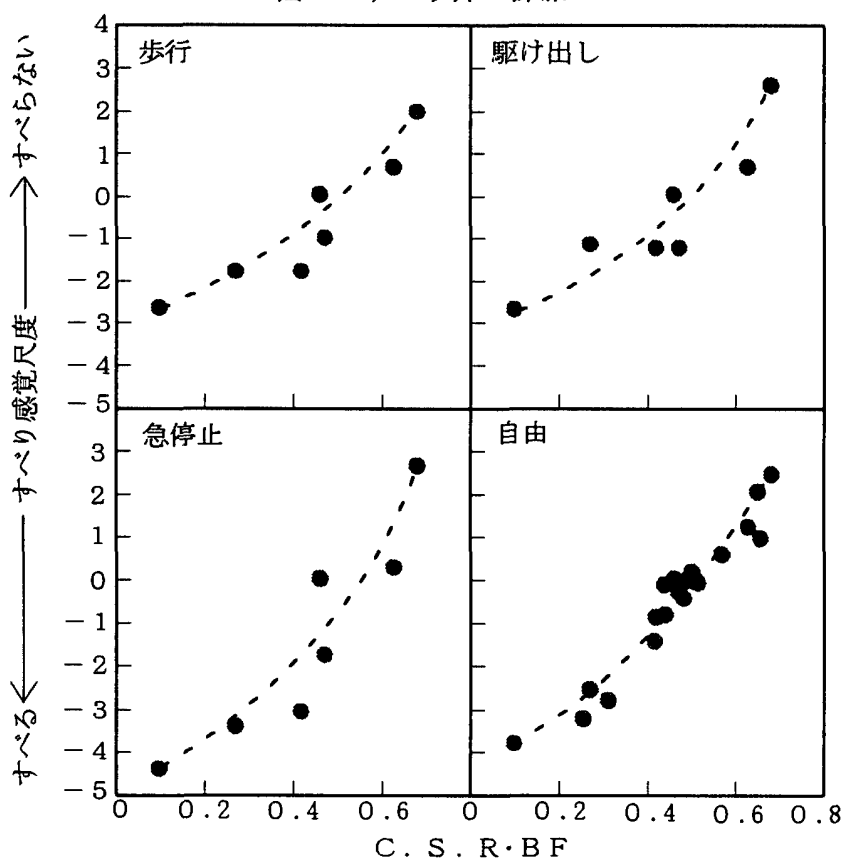

因 9 すべり感覚尺度とC.S.R・B F の対応
S . R·B F は [Pmax (kgf) /80 (kgf)] で, Pmaxは図 2 に示すの と同様である。図よりいずれの動作の場合も，両者はなめらかに対 応していることから，C．S．R・B Fを皇すへ感覚尺度を表示する すべり抵抗として設定できたといえる。

\section{7.すべり評価尺度の模成}

7.1. すへべり評価尺度構成のための官能検查の概要

7. 1.1 検查手法

検査手法は、表 4 に示す判断範ちゅうを用いて試料のすべりの良 否の絶対判断を求める系列範ちゅう法とした。

表 4 判断籍ちゅう

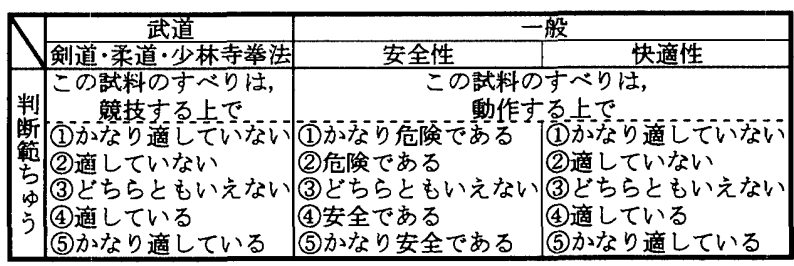

7. 1.2 検査試料の設定

多様な試料のすべりの大小をC . S . R・B Fで表示できることか ら, 本項の検査においては，検査の効率を計るため必要最小限の試 料とすること, すべりの範囲を大きくすることを主眼として, 表 3 に示すように武道の場合は11，一般の場合は13の試料を設定した。

なお，試料の大きさ，設定方法は 5.1 . 2 と同様とした。

7. 1 . 3 検查員および動作の選定

検查員の層を大きく，武道競技者，一般とした。

さらに, 武道の種目は, 動作の特徵から代表的と見なせる, 剣道, 柔道, 少林寺拳法としてそれぞれ表 3 に示す検査員を選定し, 動作 は各検査員ごとに，競技する上ですべりが重要となる動作を選択さ せることとした。

また，一般としては検查員を表 3 に示す成人男女とし, 動作とし ては歩行，方向転換，駆け出し，急停止を選定した。

7. 1.4 その他

検査室贴よび素足の管理はそれぞれ 5．1．42同様とした。

7.2.すべり評価尺度の構成および考察

7.1.に述ぺた条件で官能検 査を実施した。検査状況を写真 1 に示す。

官能検查の分散分析結果を表 3 に示す。

いずれの検查においても主効 果が高度に有意でかつ寄与率も 高いことから，検查は有効であ り，検查員はすべりの良否に関 し共通の判断基淮を有している といえる。なお個人差が有意な 場合もあるが，寄与率が主効果 と比較してきわめて小さいこと

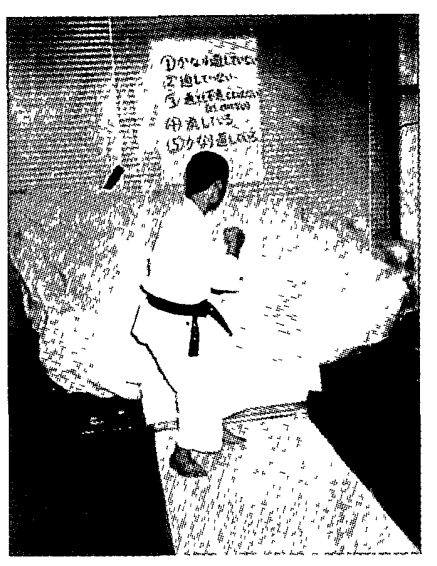

写真 1 官能検查状识 (少林寺拳法) から，すべりの良否の判断に多少の個人差があることを前提とすれ ば，大きな問題ではなく，構成される尺度は十分有効といえる。

以上から，尺度構成理論 ${ }^{16)}$ に基づきすべり評価尺度を構成した。 


\section{8.すべり評価尺度とすへり抵抗の対応およびすへり評価指枟} の提示

“図 10 にす’べり評価尺度とC．S．R・B F の対応を表す。 全体として，両者の対応は目視で描いた中心傾向を示す点線のよ うになめらかで，C．S．R・BFですべりの良否を表示できるとい える。

また両者の対応から以下の知見を得ることができる。

武道においてはいずれの場合も最適なすべり抵抗があり，すべり すぎてもすべらなさすぎても不都合といえる。このことはシューズ 装着での使用に供する他のスポーツサーフェイスの場合と本質的に 同様な傾向であり5)，6)，すべりすぎる場合は，所定の動作がしにく くなると同時に転倒しやすくなる，すべらなさすぎる場合は急停止 時に足, 腰への過大な負荷が作用する, などの理由により不都合に なると考えられる。

一方，一般に执いては，いずれの場合も，すべり抵抗が大きいほ ぞ，安全，快適といえる。このことは図 5 に例示した浴槽底，浴室 床の場合と同様の傾向であるが13314), 図 3 に例示したようにすべ りの最適值の存在が確認されている履物装着の場合1) 4) とは異な る傾向にある。一般的な床における素足での動作は，履物装着の場 合と比較して緩やかであることから，すべらなさすぎる場合の評価
が低下しないことが，理由のひとつと考えられる。

以上のように，両 者の対応から得ら゙れ る知見を説明できる ことからも，図10を 素足での床のすべり の評価指標として提 示できる。図11は図 10 の点線之評価段階 の関係から，より簡 潔な評価指標として 例示したものである。

\section{9. 秦足での床のす} ベりの評価方法の提 示

8.までの検討か ら，素足での床のす ベりを評価する方法 を以下のように提示

\begin{tabular}{|c|c|c|}
\hline \multicolumn{2}{|c|}{ 評価項目 } & $\begin{array}{ccc}\mathrm{C} & \mathrm{S} \cdot \mathrm{R} \cdot \mathrm{BF} & \\
0,2 & 0,4 & 0,6\end{array}$ \\
\hline \multirow{3}{*}{$\begin{array}{l}\text { 武 } \\
\text { 道 }\end{array}$} & 剣道 & 9 \\
\hline & 柔道 & 을 \\
\hline & 少林寺拳法 & 00 \\
\hline \multirow{4}{*}{$\begin{array}{l}\text { 般 } \\
\text { 案 } \\
\text { 羙 }\end{array}$} & 歩行 & \\
\hline & 方向転換 & \\
\hline & 駆け出し & 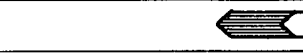 \\
\hline & 急停止 & 量 \\
\hline \multirow{4}{*}{$\begin{array}{l}\text { 般 } \\
\text { 快 } \\
\text { 適 } \\
\text { 壁 }\end{array}$} & 歩行 & . \\
\hline & 方向転換 & \\
\hline & 駆け出し & \\
\hline & 急停止 & \\
\hline
\end{tabular}

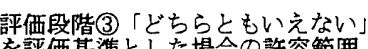
を評価基淮とした場合の許容範用

評価段階(4)「適している」, 安全である」を評価基速 とした場合の許容範囲

O: 最適值

図 11 すべりの最適值および許容算囲(例)

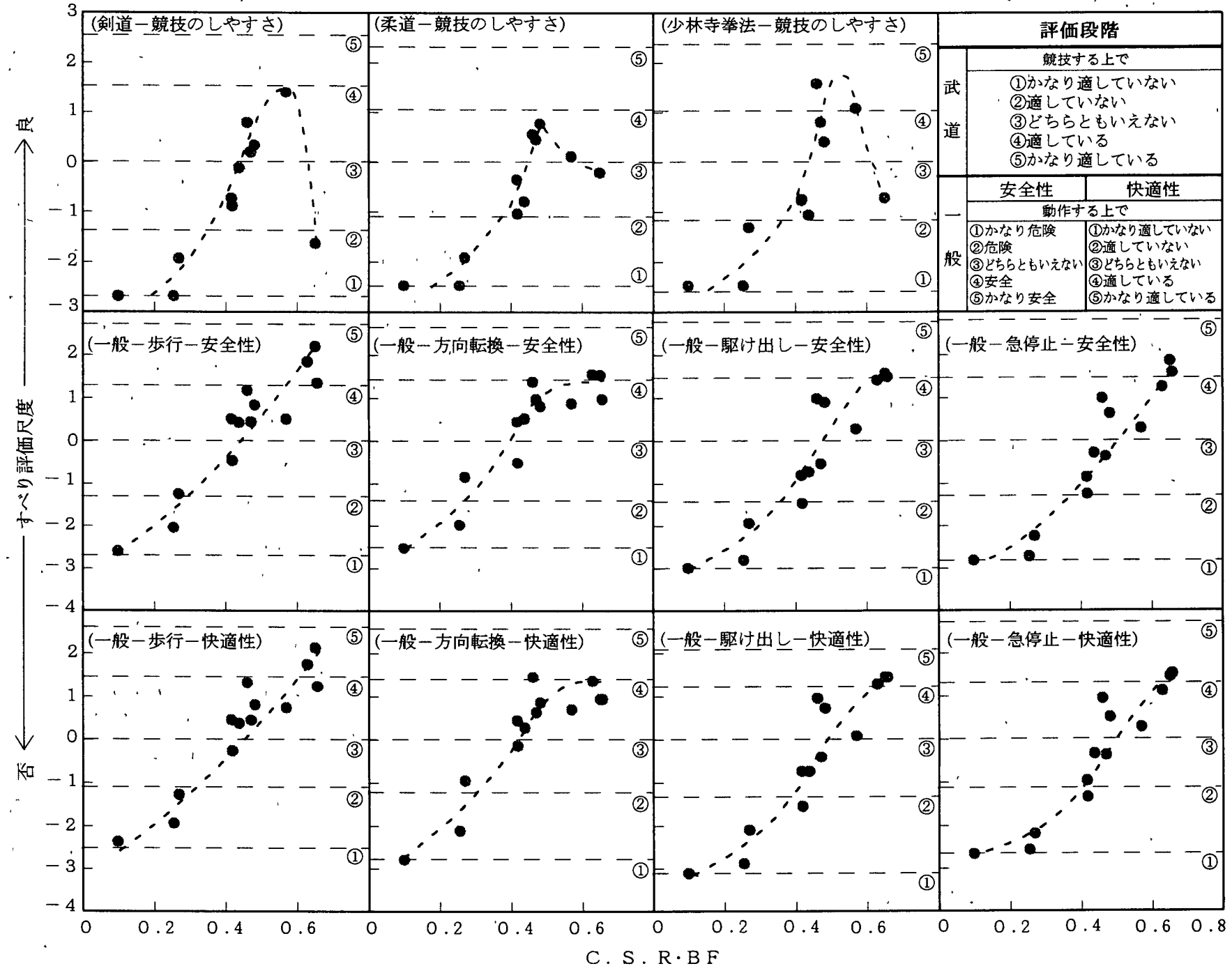

図 10 すべり評価尺度とC.S.R・B F の対応 
する。

『6.で設定した方法によりすべり抵抗を測定し，8．に示した評 価指標を用いて，当該床の素足でのすべりを評価する。』

ここで，すべり抵抗は，床と表面介在物によって決定されると考 えてよい。

また，すべりを評価する場面としては，大きく実際の使用に供し ている状態つまり有姿での評価と, 開発や設計の段階での評価,に 分けられる。

前者においては，床および表面介在物が有姿の状態ですべり抵抗 を測定すればよい。一方後者においては，実際の表面介在物を介在 させることが基本的に不可能なため，清掃状態を除けば，実際に近 似した代替介在物を設定して，すべり抵抗を測定する必要がある。

表面介在物の種類は無限にあると考えられるが，小野らは，既に 代表的な表面介在物である土砂・ほこり類, 水類（水に土砂やほこ りが混在している物質), 油類, 洗剤類, に関し, 実際の表面介在物 と同等の影響をすべり抵执に及ぼす代替介在物を設定し, JISにも規 定されている8)，15)。

素足でのすべりの場合もこれらの代替介在物を用いて評価すれば よいが，特に武道場床でのすべりに大きく影響を及ぼすとされてい る汗に関しては代替介在物を設定していない。

以上の観点から，本研究において新たに汗の代替介在物を設定す ることとした。

まず，1．におけるアンケート調查結果および 7 ．における官能 検查に協力いただいた競技者へのヒアリングにより, 汗が大きく問 題となるのは, 自分および他人の身体各部から床へしたたり落ちる 汗によってすべり抵抗が低下する場合であることを抽出した。

以上から，汗によるすべり抵抗の実際を求めるため，成人男子数 人にエアロバイク（トレーニング用マシンのひとつ）による運動で 発汗させ, 汗を必要量採取した。

つぎに, 表 3 に示寸試料のなかから清㩖状態のすべり抵抗の大小 の観点から特徴的な 5 試料を選択し, 清掃状態のC.S.R・B F お よび採取した汗を介在させた場合のC．S.R・B Fを求めた。ここ で, 汗の介在量はすべり片と休の接触部分全面に汗を過不足なく介 在させることができる $1 \mathrm{~g} / 100 \mathrm{~cm}^{2}$ とした。

つぎに, 同一試料に対し, 試行錯誤的に, 様々な表面介在物を各々

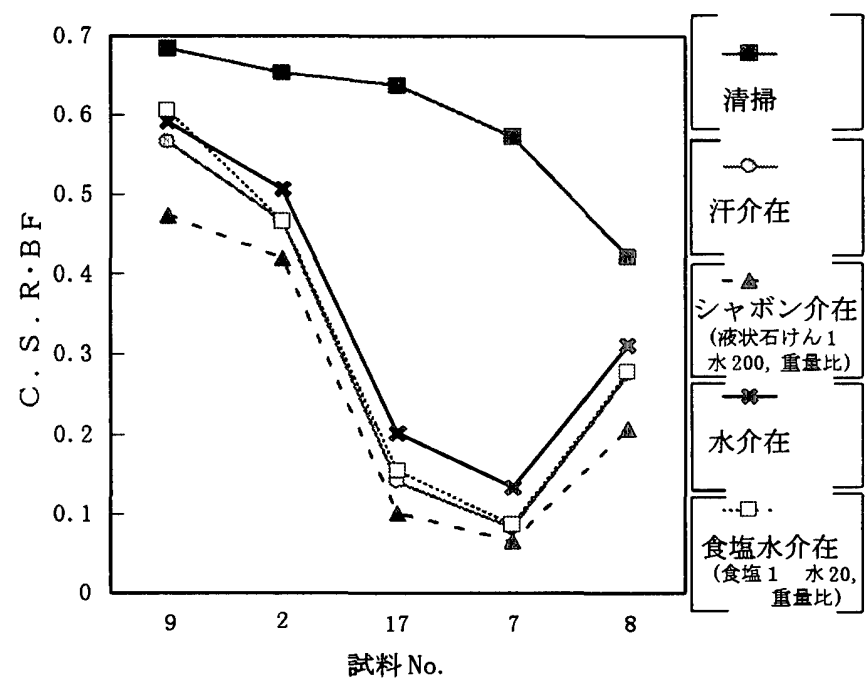

図 12 汗介在時と他の介在物介在時のC.S.R・B F の関保
汗の場合と同量介在させ C . S . R・B F を測定した。

典型的な表面介在物の場合の結果を図 12 に示すが,いずれの表面 介在物の湯合も清掃状態と比較して C. S . R B B F が低下するのが 明確で, 本研究で対象とする床においてつねに所定のすべり抵抗を 保持するためには, 表面介在物の除去つまり日常の維持管理が重要 であることがわかる。また，汗と最も近似する表面介在物は食塩水 であるのが明確なことから, 汗の代替介在物として食塩水（食塩 1 : 水 20, 重量比）を設定できる。

以上で，既往の成果をも含め8)，表面介在物の観点からもあらゆ る場合の素足でのすべりの評価が可能になったと考える。

10. 結

素足での床のすべりの評価方法を提示した。

素足での使用に供するよりよい床の開発, 設計, 維持管理のため の有用な知見として利用いただくことを期待するものである。

結びにあたり，アンタート，官能検查に協力いただいた皆様, 試 料材料を提供いただいたメーカー各位に謝意を表します。

[参考文献]

1）小野英哲，宫木宗和，河田秋澄，吉岡 丹：休のすべりおよびその評価方 法に関する研究 その1.研究方法およびすべり感営の尺度化, 日本建筑 学会諭文報告集第 321 号, 1982 年 11 月

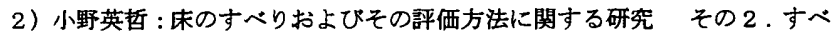
り試験機設計・試作のための基礎的試料の集積およびすべり試駼機の基本 曊想, 日本建築学会踰文報告集第 333 号, 1983 年 11 月

3）小野英哲, 河田秋登, 宮木宗和, 川村清志, 小西敏正, 三上貫正, 橋田 浩, 吉岡 丹:休のすべりおよびその評価方法に関する研究 その $3 . す$ べり試験機の設計・試作，日本建案学会諭文叝告集第 346 号，1984 年12月

4) 小野英哲, 須藤 拓, 吉岡 丹: 林のすべりの評価指標およひ棓価方法の 提示, 床のすべりおよびその評価方法に関する研究 (その 4), 日本建筑 学会權造系論文報告集第 356 号, 1985 年 10 月

5）小野英晢, 橋田 浩, 横山 裕: スポーツサーフェイスのすべりの評価方 法に関する研究，日本建築学会棈造系論文報告集第 359 号, 1986 年1月

6）小野英括, 三上贵正, 岩崎淑子, 横山裕 : エアロビックダンスフロアの かたさ,すべりの評価方法に関する研究, 日本建筑学会橦造系嘼文報告集 第 385 号, 1988 年 3 月

7) 小野英拍, 北山 大, 高橋宏樹 : 安全性からみた斜路のすべりの平価方法 に関する研究, 日本建築学会構造系論文報告集第 448 号, 1993 年 6 月

8）小野英哲，三上贵正，高木 直，横山 裕，北山 大，高橋宏樹 : 休のす

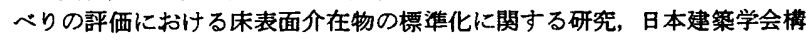
造系踰文報告集第 450 号, 1993 年 8 月

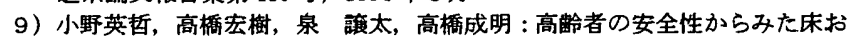
上び斜路のすべりの評価方法の提示, 日本建筑学会棰造系論文集第 484 号, 1996 年 6 月

10）小野英哲，須藤 拓，三上贵正 : 安全性からみた階段のすべりの評価方法 に関する基礎的考察，安全性からみた階段のすべりの評価方法に関する研 究 (その 1$)$, 日本建筑学会構造系論文報告集第 362 号, 1986 年 4 月

11）小野英哲, 武田 清, 水田久雄 : 階段各部分のすべり抵抗の測定, 安全性 からみた陵段のすべりの評価方法に関する研究 (その2), 日本建策学会 幥造系踰文報告集第 373 号, 1987 年 3 月

12）小野英哲, 武田 清, 三上貴正, 大野隆造 : 安全性からみた階段のすべり の評扸方法の提示, 安全性からみた階段のすへりの評価方法関する研究 (その 3 ), 日本建築学会構造系論文報告集第 383 号, 1988 年 1 月

13）小野英哲，上野静二，横山 裕，大野隆造，三上貴正：安全性加らみた谷 室㦿および谷槽底のすべりの評価方法に関する研究，その 1 すべり抵抗 の測定方法の設定およひ浴槽断面寸法の設定, 日本建筑学会桡造系踰文報 告集第 384 号, 1988 年 2 月

14）小野英哲, 三上貴正, 大野隆造, 横山 裕, 上野静二, 高木 直: 安全性 からみた浴室床および谷槽底のすべりの評価方法に関する研究，その 2 すへりの評価指摽求よび評価方法の提示, 日本建築学会構造系論文報告集 第 387 号, 1988 年 5 月

15）JIS A 1454 「高分子系張り床試験方法一 Test Methods - Resil1ent Floorcoverings」

16）Guilford，J.P，秋重義治監訳：精神測定法，培風館，1959 年 9 月 (2000年 3 月 10 日原稿受理， 2000 年 7 月 3 日操用决定） 